\title{
RETROSPECTIVE VALIDATION OF A STRUCTURE-BASED VIRTUAL SCREENING PROTOCOL TO IDENTIFY LIGANDS FOR ESTROGEN RECEPTOR ALPHA AND ITS APPLICATION TO IDENTIFY THE ALPHA-MANGOSTIN BINDING POSE
}

\author{
Agustina Setiawati ${ }^{1}$, Florentinus Dika Octa Riswanto ${ }^{2}$, Sri Hartati Yuliani $^{3}$, \\ and Enade Perdana Istyastono $0^{2,3,4, *}$ \\ ${ }^{1}$ Laboratory of Pharmacognosy-Phytochemistry, Faculty of Pharmacy, Sanata Dharma University, \\ Paingan, Maguwoharjo, Depok, Yogyakarta 55284, Indonesia \\ ${ }^{2}$ Laboratory of Pharmaceutical Chemistry, Faculty of Pharmacy, Sanata Dharma University, \\ Paingan, Maguwoharjo, Depok, Yogyakarta 55284, Indonesia \\ ${ }^{3}$ Laboratory of Pharmaceutical Technology, Faculty of Pharmacy, Sanata Dharma University, \\ Paingan, Maguwoharjo, Depok, Yogyakarta 55284, Indonesia \\ ${ }^{4}$ Center for Environmental Studies Sanata Dharma University (CESSDU), \\ Soropadan, Condongcatur, Depok, Yogyakarta 55283, Indonesia
}

Received April 23, 2014; Accepted June 6, 2014

\begin{abstract}
The publicly available enhanced data of ligands and decoys for estrogen receptor alpha (ERa) which were recently published has made the retrospective validation of a structure-based virtual screening (SBVS) protocol to identify ligands for ERa possible. In this article, we present the retrospective validation of an SBVS protocol using PLANTS molecular docking software version 1.2 (PLANTS1.2) as the backbone software. The protocol shows better enrichment factor at $1 \%$ false positives $\left(E F_{1 \%}\right)$ value and the Area Under Curve $(A U C)$ value of the Receiver Operator Characteristic (ROC) compared to the original published protocol. Moreover, in all 1000 iterative attempts the protocol could reproduce the co-crystal pose of 4-hydroxitamoxifen in ERa binding pocket. It shows that the protocol is not only able to identify potent ligands for ERa but also able to be employed in examining binding pose of known ligand. Hence, the protocol was successfully employed to examine the binding poses of $\alpha$-mangostin, an ER $\alpha$ ligand found in the Garcinia mangostana, L. pericarp.
\end{abstract}

Keywords: Structure-based virtual screening (SBVS); molecular docking; estrogen receptor alpha (ERa); $\alpha$ mangostin

\begin{abstract}
ABSTRAK
Keberadaan data termutakhir ligan-ligan reseptor estrogen alfa (ER $)$ beserta pengecohnya memungkinkan dilakukan validasi retrospektif pada protokol-protokol Penapisan Virtual Berbasis Struktur (PVBS) yang dikembangkan untuk identifikasi ligan-ligan ERa. Artikel ini membahas validasi retrospektif protokol PVBS yang menggunakan aplikasi penambatan molekuler PLANTS versi 1,2 (PLANTS1.2) sebagai tulang punggung protokol tersebut dalam identifikasi ligan-ligan ERa. Hasil validasi retrospektif menunjukkan bahwa protokol yang dikembangkan memiliki nilai faktor pengayaan pada $1 \%$ false positives $\left(E F_{1 \%}\right)$ dan nilai di bawah kurva dari Receiver Operator Characteristic (ROC) yang lebih baik daripada protokol original yang dipublikasikan bersama data ligan dan pengecoh. Protokol tersebut juga divalidasi untuk melihat kemampuannya dalam menambatkan senyawa aktif dengan penambatan ulang 1000 kali ligan ko-kristal 4-hidroksitamoksifen pada kantung ikatan ERa. Dalam 1000 kali iterasi, keseluruhan simulasi menunjukkan kemampuan protokol dalam mereproduksi pose ko-kristal. Hal ini menunjukkan bahwa protokol yang dikembangkan memiliki kemampuan untuk identifikasi ligan-ligan poten pada $E R \alpha$ dan menambatkan ligan ERa dengan tepat di kantung ikatan. Oleh karena itu, protokol tervalidasi ini selanjutnya digunakan untuk meneliti pose-pose ikatan a-mangostin, senyawa aktif yang terdapat pada kulit manggis (Garcinia mangostana, L.).
\end{abstract}

Kata Kunci: Penapisan virtual berbasis struktur (PVBS); penambatan molekuler; receptor estrogen alfa (ERa); $\alpha$ mangostin

* Corresponding author.

Email address : enade@usd.ac.id

Agustina Setiawati et al. 


\section{INTRODUCTION}

As the $1^{\text {st }}$ leading cause of death in the developed countries and the $2^{\text {nd }}$ in the developing countries, cancer is a major health problem in the world [1]. Among other cancers, breast cancer is ranked the $1^{\text {st }}$ as leading cause of death for women [1-2]. In Yogyakarta, local data for cancer shows that in 2005 (data from 19982004), breast cancer was the highest prevalence cancer with $26 \%$ of the patients were less than 40 years old [3]. Among other molecular determinants in breast cancer development, estrogen receptor $\alpha(E R \alpha)$ is one of molecular targets in the therapy [4]. Tamoxifen, one of drug of choice in breast cancer therapy [5], is targeting ERa. Tamoxifen itself is a ligand with high affinity for $\mathrm{ERa}$, which is metabolized to 4-hydroxytamoxifen and $\mathrm{N}$-des-methyl-4-hydroxo-tamoxifen with affinities circa 30 to 100 times stronger than tamoxifen for ERa [6]. Fortunately, the ERa crystal structure with 4-hydroxytamoxifen as its co-crystal ligand is publicly available in the Protein Data Bank (PDB) with the PDB code of 3ERT (Fig. 1) [7], which could be employed to be a virtual target to identify potential ERa fragments [8]. On the other hand, a public database of enhanced useful decoys (A database of useful decoys: Enhanced (DUDe)) has recently published for 102 molecular drug targets, including ERa [9]. The article presenting DUD-e shows that employing ERa as the molecular target in a structure-based virtual screening (SBVS) campaign gave enrichment factor at $1 \%$ false positives $\left(E_{1 \%}\right)$ value and the Area Under Curve (AUC) value of the Receiver Operator Characteristic (ROC) of 15.4 and $67.48 \%$, respectively [9]. Some improvements in the virtual screening protocol are therefore required to have more convincing SBVS tools [10]. Therefore, development of SBVS protocols to discover drugs in order to cure or even to prevent the development of breast cancer by targeting ERa is of considerable and timely interest.

In this post genomics era, the development of computer technology is remarkably boosting and assisting the drug discovery and development [11]. One of developing technique in the field is structure-based drug design and discovery [10,12-15], which uses the availability of the three-dimensional (3D) structures of the protein targets $[7,9,16-17]$ to identify or even to design novel ligands [14]. The availability of ERa structure and its ligands and decoys (which has been publicly available since 2006 in a database of useful decoys (DUD) [17]) has led some attempts to construct valid SBVS protocols to identify novel ligands for ERa [8-9,17-18]. By employing PLANTS docking software [19], Anita et al. [8] has developed and retrospectively validated SBVS protocol to identify ERa ligands. The protocol showed a better VS quality compared to the original protocol accompanying the publication of the

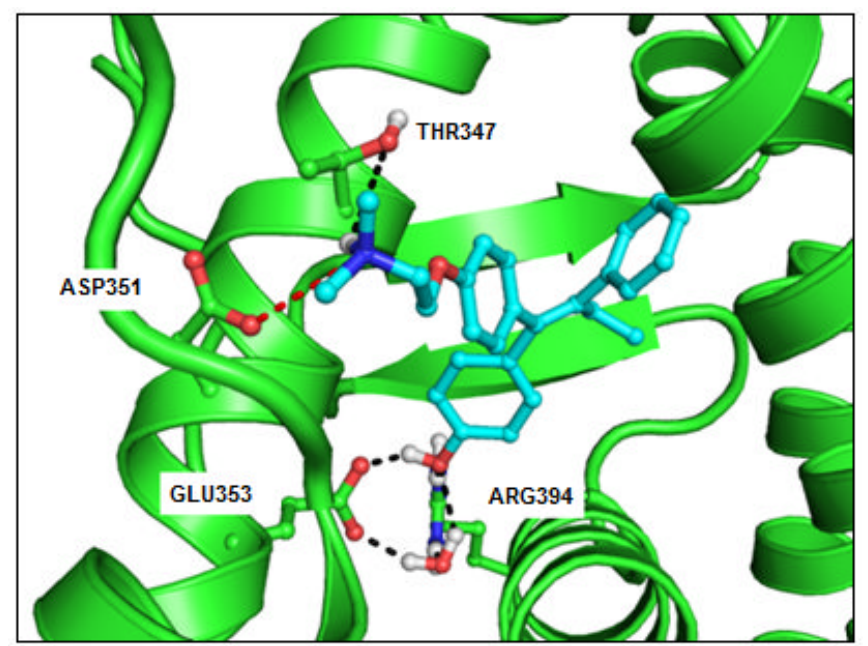

Fig 1. The co-crystal ligand 4-hydroxytamoxifen (carbon atoms are in cyan) in the ERa (carbon atoms are in green) binding pocket [7]. The ERa is presented in the cartoon mode, while the crystal structure pose is presented in the sticks mode. Only polar hydrogens (presented in white), residues (presented in sticks mode, carbon atoms are in green) with hydrogen bond interaction (presented in black dashes) and ionic interaction (presented in red dashes) to the ligand, and a conserved water molecule [8] are presented for the sake of clarity. Nitrogen and oxygen atoms are presented in blue and red, respectively<smiles>COc1c(O)cc2oc3cc(O)c(CC=C(C)C)c(O)c3c(=O)c2c1CC=C(C)C</smiles>

Fig 2. Structure $\alpha$-mangostin [21]

ligands and decoys by Huang et al. [17]. Subsequently, in order to test the applicability of a software to identify protein-ligand interaction fingerprints PyPLIF in a SBVS campaign, Radifar et al. [18] re-scored and re-validated the results from the SBVS protocol constructed by Anita et al. [8]. PyPLIF-aided SBVS protocol showed a significant increase in quality by filtering on the hydrogen bond interactions of the ligands to the ASP351 of the ERa [18]. Interestingly, the co-crystal ligand 4-hydroxytamoxifen in the crystal structure of the ERa (3ERT.pdb) does not have the hydrogen bond interactions to the ASP351 of the ERa (Fig. 1) [7]. The SBVS protocol developed by Radifar et al. [18] is therefore not able to reproduce the pose of the co-crystal ligand in the crystal structure of the ERa. During the fine tuning to have a valid SBVS protocol that is able to identify ligands and to reproduce the co-crystal pose, a new enhanced database of useful 


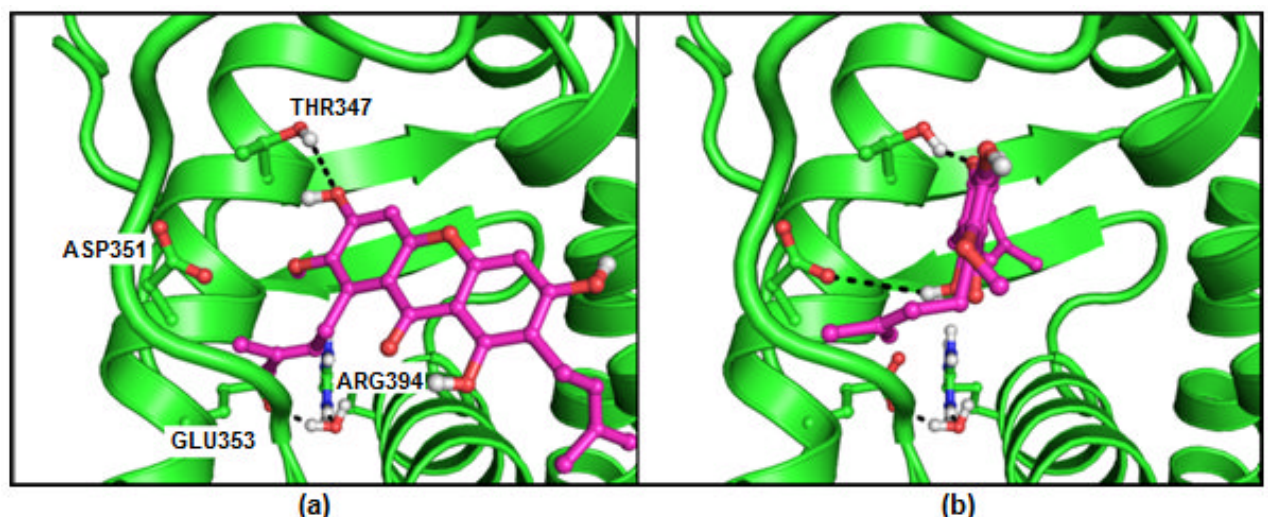

Fig 3. The representatives of the identified binding poses of a-mangostin (carbon atoms are in magenta) in the ERa (carbon atoms are in green) binding pocket [7] from cluster 1 (a) and cluster 2 (b). The rendering is similar to Fig. 1

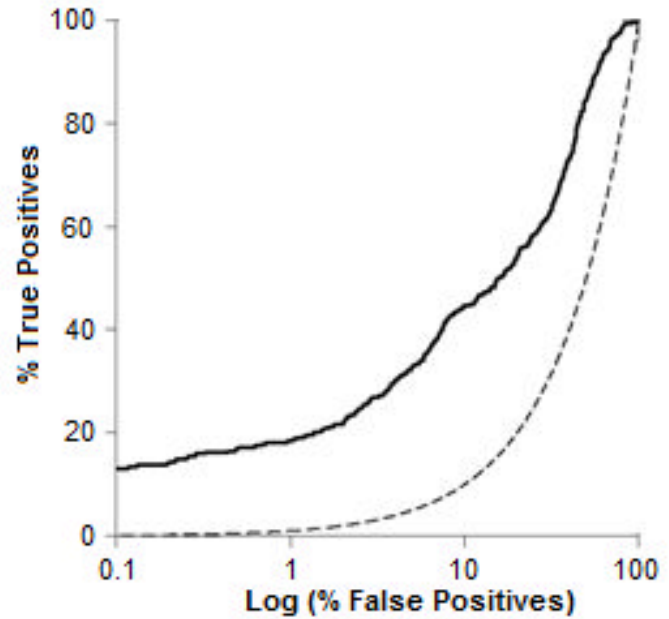

Fig 4. The ROC curves of the SBVS protocol developed in this research (solid line) and the random sampling (dashed line)

decoys DUD-e was published for 102 molecular drug targets, including ERa [9]. This database has more ligands and decoys compared to DUD $[9,17]$.

This research aimed to develop a robust computational medicinal chemistry tool in order to discover novel ERa ligands and to examine the binding poses of known ERa ligands. In this article, the retrospective validation of a modified SBVS protocol developed by Anita et al. [8] using the DUD-e database is presented. The validated protocol was subsequently examined to see its ability to reproduce the pose of the co-crystal ligand in the ERa binding pocket and to examine the binding pose of a-mangostin (Fig. 2), an ERa ligand found in the Garcinia mangostana, L. pericarp [20-21]. The modified SBVS protocol developed in this research showed better VS quality compared to the original SBVS protocol accompanying the publication of DUD-e [9] and was able to reproduce the pose of the co-crystal ligand [7]. Two distinct binding poses of a-mangostin in the ERa binding pocket (Fig. 3) were identified using the retrospectively validated protocol in this research.

\section{METHODS}

\section{Materials}

A dataset of ERa ligands (383 compounds) and their decoys $(20,685$ compounds) in file type of . mo/2 obtained from DUD-e [9]. The ERa crystal structure and its co-crystal ligand 4-hydroxytamoxifen (3ERT.pdb) downloaded from Protein Data Bank (PDB) submitted by Shiau et al. [7]. Configuration files to perform molecular docking simulations in order to perform SBVS to identify ligands for ERa using PLANTS docking software prepared by Anita et al. [8]: (i) The virtual target protein.mo/2, (ii) the conserved water molecule water.mol2, and (iii) the configuration files to run PLANTS docking software plants.config.

\section{Computation Details}

Computational medicinal chemistry applications used in this research were: PLANTS docking software version 1.2 (PLANTS1.2) [19,22] to perform molecular docking simulations, $\mathrm{R}$ computational statistics software to calculate $\mathrm{EF}_{1 \%}$ and $A U C$ and to perform statistical tests [23] and PyMOL [24, 25] to calculate the root mean square distances (RMSD) values and to generate molecular pictures. All calculations and computational simulations were performed on a Linux (Ubuntu 10.04 LTS Lucid Lynx) machine with Intel ${ }^{(R)}$ Xeon ${ }^{(R)}$ CPU E31220 (@ $3.10 \mathrm{GHz}$ ) as the processors and $8.00 \mathrm{~GB}$ of RAM.

\section{Procedure}

Every compound downloaded from DUD-e [9] were docked independently three times in the binding 


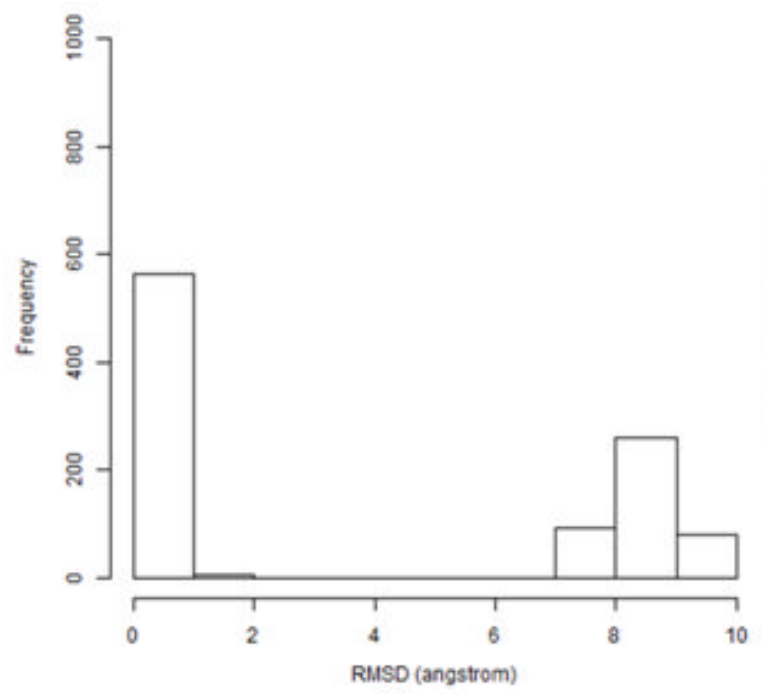

(a)

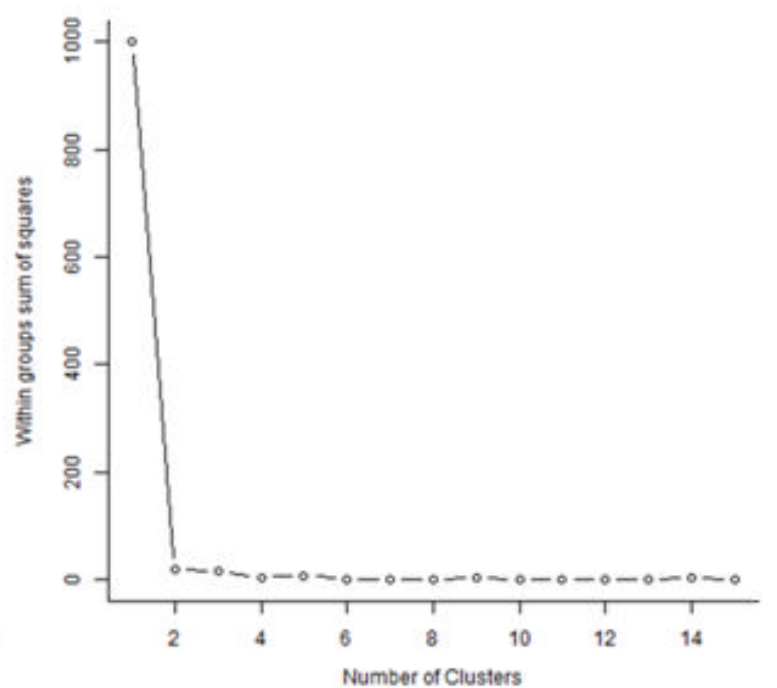

(b)

Fig 5. The histogram (a) and the Scree plot (b) of the RMSD values of $\alpha$-mangostin docking poses compared to its binding pose with the best ChemPLP value

pocket of ERa by using configuration files from Anita et al. [8]. Every run resulted in 50 docked poses. Therefore, every compound had 150 poses. The best pose of each compound was selected as the pose with the best ChemPLP score [19]. The compounds were then ranked based on their ChemPLP score [10]. The $\mathrm{EF}_{1 \%}$ and the AUC values were then calculated [26] by using $\mathrm{R}$ computational statistics software [23].

The similar procedure was performed to dock cocrystal ligand 4-hidroxytamoxifen in the ERa binding pocket 1000 times to see the ability of the protocol to reproduce the pose of the co-crystal ligand. The best poses collected in every run were compared to the pose of the co-crystal ligand and the RMSD values were calculated by using PyMOL $[24-25,27]$. The protocol was considered as acceptable in reproducing the co-crystal ligand pose if resulted in the RMSD value of less than $2.0 \AA[28]$.

The same procedure to dock co-crystal ligand 4-hidroxytamoxifen in the ERa binding pocket was performed to dock a-mangostin which resulted in 1000 poses. Those poses were compared to the pose with the best ChemPLP score and the RMSD values were calculated [27]. Based on the RMSD values, the poses were clustered by employing $k$-means clustering [29] in $\mathrm{R}$ computational statistics software [27].

\section{RESULT AND DISCUSSION}

This research aimed to retrospectively validate an SBVS protocol in order to develop a tool to identify ERa ligands and to examine the binding poses of identified ERa ligands. The SBVS protocol used in the research was initially developed by Anita et al. [8] and has been modified in this research. The modification in the SBVS protocol was using three independent molecular docking simulations for each compound instead of one as performed in the initial SBVS protocol [8]. One of the advantages of using some more independent simulations is that we can sample more converged docking poses for every compounds although it increases the computing cost [27,30-31].

Fig. 4 presents the ROC of the \% true positives (\%TP) and \% false positives (\%FP) results from the retrospective validations to identify ERa ligands by employing the DUD-e dataset $[9,26]$. The retrospective validation showed that the $\mathrm{EF}_{1 \%}$ value of the modified protocol was 18.54 (Fig. 4). This $\mathrm{EF}_{1 \%}$ value is higher than the $\mathrm{EF}_{1 \%}$ value of original SBVS protocol (15.4) [9]. The $\mathrm{EF}_{1 \%}$ represents the early enrichment results from the protocol. The higher the $\mathrm{EF}_{1 \%}$ value, the better the protocol in the identification of known ERa ligands is $[9,26]$. It means that in the first $1 \%$ of the ranked database the protocol can identify known ligands and put them in the higher rank compared to their decoys $[9,26]$. Based on Fig. 4, the AUC value could be calculated by using pROC package in $R$ computational statistics software [23]. The AUC value resulted from the retrospective validations was $76.41 \%$ with $95 \%$ confidence interval of $74.05 \%-78.78 \%$. This value is also better than the AUC value of the original protocol $(67.48 \%)$ [9]. The ideal value of the AUC is $100 \%$ [26], which indicates that all known ligands are ranked higher than their decoys. In random sampling, the AUC value is $50 \%$ [32]. The $\mathrm{EF}_{1 \%}$ value represents the early enrichment of the protocols, while the AUC value represents the global enrichment [26,32]. Since the $\mathrm{EF}_{1 \%}$ and $\mathrm{AUC}$ values of the SBVS protocol develop in 
this research are better than the original protocol [9], we are confident that the protocol is more robust to identify ERa ligands.

The developed protocol was intended to be employed also in the examination of the binding pose of known ERa ligands. The protocol was then challenged to redock the co-crystal ligands 4-hydroxytamoxifen in the ERa binding pocket [7] for 1000 times [27,31]. Remarkably, in all redocking simulations the protocol showed its ability to reproduce the co-crystal pose with RMSD values of $<2.00 \AA$. The developed protocol in this research is therefore able to identify ERa ligands and to examine their binding pose in the ERa binding pocket.

The protocol was then employed to examine the binding pose of a-mangostin (Fig. 2) resulted in 1000 selected poses from 1000 different iterations of the protocol. The compound a-mangostin, which can be found in the pericarp of Garcinia mangostana, L. [21,33] is a known ligand for ERa [21,33]. Garcinia mangostana, L. has recently gained its popularity [34] due to its applications as herbal medicines to treat inflammation and bacterial infections [33] as well as its application in cancer chemoprevention [35]. Therefore, it is of interest to select a-mangostin as the lead compound in the structure-based drug design in this research. By examining the RMSD values of the poses compared to the pose with the best ChemPLP value presented in a histogram and a Scree plot in Fig. 5, two distinct poses of a-mangostin were identified (Fig. 3). Interestingly, both poses shows that a-mangostin located in the ERa binding pocket (Fig. 3) only in the subpocket where the co-crystal ligand 4-hydroxytamoxifen interacts to THR347 and ASP351 (Fig. 1). a-mangostin could not go to the subpocket where 4-hydroxytamoxifen interacts to GLU353 and ARG394 (Fig. 1). This indicates that referring to 4-hydroxytamoxifen as the co-crystal ligand, a-mangostin interacts to ERa as an allosteric ligand.

\section{CONCLUSION}

The SBVS protocol developed in this research is a robust computational tool to identify ERa ligands and to examine their poses in the binding pocket ERa. The application of the SBVS protocol to examine the binding poses of a known ERa ligand a-mangostin resulted in two distinct binding poses. The binding poses of a-mangostin indicate that it interacts in the allosteric site of ERa.

\section{ACKNOWLEDGEMENT}

This work was supported by Sanata Dharma University Special Internal Research Grant 2013 (No. 083/Panel/LPPM USD/SP/X/2013).

\section{REFERENCES}

1. Siegel, R., Naishadham, D., and Jemal, A., 2012, CA Cancer J. Clin., 62 (1), 10-29.

2. Jemal, A., Bray, F., and Ferlay, J., 2011, CA Cancer J. Clin., 61 (2), 69-90.

3. Purnomosari, D., 2006, PhD Thesis, VU University, Amsterdam.

4. Harvey, J.M., Clark, G.M., Osborne, C.K., and Allred, D.C., 1999, J. Clin. Oncol., 17 (5), 1474-1481.

5. Mouridsen, H., Giobbie-Hurder, A., Goldhirsch, A., Thürlimann, B., Paridaens, R., Smith, I., Mauriac, L., Forbes, J.F., Price, K.N., Regan, M.M., Gelber, R.D., and Coates, A.S., 2009, N. Engl. J. Med., 361 (8), 766-776.

6. Desta, Z., Ward, B.A., Soukhova, N.V., and Flockhart, D.A., 2004, J. Pharmacol. Exp. Ther., 310 (3), 1062-1075.

7. Shiau, A.K., Barstad, D., Loria, P.M., Cheng, L., Kushner, P.J., Agard, D.A., and Greene, G.L., 1998, Cell, 95 (7), 927-937.

8. Anita, Y., Radifar, M., Kardono, L., Hanafi, M., and Istyastono, E.P., 2012, Bioinformation, 8 (19), 901-906.

9. Mysinger, M.M., Carchia, M., Irwin, J.J., and Shoichet, B.K., 2012, J. Med. Chem., 55 (14), 6582-6594.

10. De Graaf, C., Kooistra, A.J., Vischer, H.F., Katritch, V., Kuijer, M., Shiroishi, M., Iwata, S., Shimamura, T., Stevens, R.C., de Esch, I.J.P., and Leurs, R., 2011, J. Med. Chem., 54 (23), 8195-8206.

11. Van Gunsteren, W.F., Bakowies, D., Baron, R., Chandrasekhar, I., Christen, M., Daura, X., Gee, P., Geerke, D.P., Glättli, A., Hünenberger, P.H., Kastenholz, M.A., Oostenbrink, C., Schenk, M., Trzesniak, D., van der Vegt, N.F.A., and Yu, H.B., 2006, Angew. Chem. Int. Ed., 45 (25), 4064-4092.

12. Kooistra, A.J., Leurs, R., de Esch, I.J.P., and de Graaf, C., 2014, "From Three-Dimensional GPCR Structure to Rational Ligand Discovery" in G Protein-Coupled Receptors - Modeling and Simulation., Ed. Filizola, M., Springer Netherlands, 129-157.

13. De Graaf, C., Oostenbrink, C., Keizers, P.H.J., van der Wijst, T., Jongejan, A., and Vermeulen, N.P.E., 2006, J. Med. Chem., 49 (8), 2417-2430.

14. Istyastono, E.P., Nijmeijer, S., Lim, H.D., van de Stolpe, A., Roumen, L., Kooistra, A.J., Vischer, H.F., de Esch, I.J.P., Leurs, R., and de Graaf, C, 2011, J. Med. Chem., 54 (23), 8136-8147.

15. Sirci, F., Istyastono, E.P., Vischer, H.F., Kooistra, A.J., Nijmeijer, S., Kuijer, M., Wijtmans, M., Mannhold, R., Leurs, R., de Esch, I.J.P., and de 
Graaf, C., 2012, J. Chem. Inf. Model., 52 (12), 3308-3324.

16. Irwin, J.J., Sterling, T., Mysinger, M.M., Bolstad, E.S., and Coleman, R.G., 2012, J. Chem. Inf. Model., 52 (7), 1757-1768.

17. Huang, N., Shoichet, B.K., and Irwin, J.J., 2006, J. Med. Chem., 49 (23), 6789-6801.

18. Radifar, M., Yuniarti, N., and Istyastono, E.P., 2013, Bioinformation, 9 (6), 325-328.

19. Korb, O., Stützle, T., and Exner, T.E., 2009, J. Chem. Inf. Model., 49, 1, 84-96.

20. Hopert, A.C., Beyer, A., Frank, K., Strunck, E., Wünsche, W., and Vollmer, G., 1998, Environ. Health Perspect., 106 (9), 581-586.

21. Shibata, M.A., linuma, M., Morimoto, J., Kurose, H., Akamatsu, K., Okuno, Y., Akao, Y., and Otsuki, Y., 2011, BMC Med., 9 (69), 1-18.

22. Korb, O., Stützle, T., and Exner, T.E., 2007, Swarm Intell., 1 (2), 115-134.

23. Robin, X., Turck, N., Hainard, A., Tiberti, N., Lisacek, F., Sanchez, J.C., and Müller, M., 2011, BMC Bioinf., 12 (77), 1-8.

24. Lill, M.A., and Danielson, M.L., 2011, J. Comput. Aided Mol. Des., 25 (1), 13-19.

25. The PyMOL Molecular Graphics System, Version 1.2r1, Schrödinger, LLC.
26. De Graaf, C., and Rognan, D., 2008, J. Med. Chem., 51 (16), 4978-4985.

27. Istyastono, E.P., 2012, Indo. J. Chem., 12 (2), 141-145.

28. Marcou, G., and Rognan, D. 2007, J. Chem. Inf. Model., 47 (1), 195-207.

29. Shi, W., and Zeng, W., 2013, Int. J. Environ. Res. Public Health, 10 (6), 2578-2595.

30. Wijtmans, M., de Graaf, C., de Kloe, G., Istyastono, E.P., Smit, J., Lim, H., Boonnak, R., Nijmeijer, S., Smits, R.A., Jongejan, A., Zuiderveld, O., de Esch, I.J.P., and Leurs, R., 2011, J. Med. Chem., 54 (6), 1693-1703.

31. Radifar, M., Yuniarti, N., and Istyastono, E.P., 2013, Indo. J. Chem., 13 (3), 283-286.

32. Jain, A.N., and Nicholls, A., 2008, J. Comput. Aided Mol. Des., 22 (3-4), 133-139.

33. Yodhnu, S., Sirikatitham, A., and Wattanapiromsakul, C., 2009, J. Chromatogr. Sci., 47 (3), 185-189.

34. Purwanto, A., 2008, Skripsi, Universitas Sebelas Maret Surakarta

35. Balunas, M.J., Su, B., Brueggemeier, R.W., and Kinghorn, A., 2008, J. Nat. Prod., 71 (7), 11611166. 